\title{
PM-Bound Polycyclic Aromatic Hydrocarbons and Nitro-Polycyclic Aromatic Hydrocarbons in the Ambient Air of Vladivostok: Seasonal Variation, Sources, Health Risk Assessment and Long-Term Variability
}

\author{
Yan Wang ${ }^{1}{ }^{(}$, Hao Zhang ${ }^{1}$, Xuan Zhang ${ }^{1}{ }^{(}$, Pengchu Bai ${ }^{1}{ }^{\circledR}$, Andrey Neroda ${ }^{2}$, Vassily F. Mishukov ${ }^{2}$, \\ Lulu Zhang ${ }^{3}$, Kazuichi Hayakawa ${ }^{3}$, Seiya Nagao ${ }^{3}$ and Ning Tang ${ }^{3,4, *(1)}$ \\ 1 Graduate School of Medical Sciences, Kanazawa University, Kanazawa 9201192, Japan; \\ wangyan@stu.kanazawa-u.ac.jp (Y.W.); zhanghao@stu.kanazawa-u.ac.jp (H.Z.); \\ zhangxuan@stu.kanazawa-u.ac.jp (X.Z.); baipengchu@stu.kanazawa-u.ac.jp (P.B.) \\ 2 Pacific Oceanological Institute, Far Eastern Branch, Russian Academy of Sciences, \\ 690041 Vladivostok, Russia; aneroda@poi.dvo.ru (A.N.); vmishukov@poi.dvo.ru (V.F.M.) \\ 3 Institute of Nature and Environmental Technology, Kanazawa University, Kanazawa 9201192, Japan; \\ zhang-lulu@se.kanazawa-u.ac.jp (L.Z.); hayakawa@p.kanazawa-u.ac.jp (K.H.); \\ seiya-nagao@se.kanazawa-u.ac.jp (S.N.) \\ 4 Institute of Medical, Pharmaceutical and Health Sciences, Kanazawa University, Kanazawa 9201192, Japan \\ * Correspondence: n_tang@staff.kanazawa-u.ac.jp; Tel.: +81-76-34-4455
}

check for updates

Citation: Wang, Y.; Zhang, H.; Zhang, X.; Bai, P.; Neroda, A.; Mishukov, V.F.; Zhang, L.; Hayakawa, K.; Nagao, S.; Tang, N. PM-Bound Polycyclic Aromatic Hydrocarbons and Nitro-Polycyclic Aromatic Hydrocarbons in the Ambient Air of Vladivostok: Seasonal Variation, Sources, Health Risk Assessment and Long-Term Variability. Int. J. Environ. Res. Public Health 2022, 19, 2878. https://doi.org/10.3390/ ijerph19052878

Academic Editor: Paul B. Tchounwou

Received: 6 February 2022

Accepted: 28 February 2022

Published: 1 March 2022

Publisher's Note: MDPI stays neutral with regard to jurisdictional claims in published maps and institutional affiliations.

Copyright: (C) 2022 by the authors. Licensee MDPI, Basel, Switzerland. This article is an open access article distributed under the terms and conditions of the Creative Commons Attribution (CC BY) license (https:// creativecommons.org/licenses/by/ $4.0 /)$.

\begin{abstract}
Total suspended particles (TSP) were collected in Vladivostok, Russia, which is a typical port city. This study investigated the concentration, potential sources, and long-term variation in particle PAHs and NPAHs in the atmosphere of Vladivostok. The PAH and NPAH concentrations were higher in winter than in summer (PAHs: winter: $18.6 \pm 9.80 \mathrm{ng} / \mathrm{m}^{3}$ summer: $0.54 \pm 0.21 \mathrm{ng} / \mathrm{m}^{3}$; NPAHs: winter: $143 \pm 81.5 \mathrm{pg} / \mathrm{m}^{3}$ summer: $143 \pm 81.5 \mathrm{pg} / \mathrm{m}^{3}$ ). The diagnostic ratios showed that PAHs and NPAHs mainly came from vehicle emissions in both seasons, while heating systems were the main source of air pollution in winter. The TEQ assessment values were $2.90 \mathrm{ng} / \mathrm{m}^{3}$ and $0.06 \mathrm{ng} / \mathrm{m}^{3}$ in winter and summer, respectively, suggesting a significant excess cancer risk in the general population in winter. The ILCR values conveyed a potential carcinogenic risk because the value was between $1 \times 10^{-5}$ and $1 \times 10^{-7}$ and ingestion was a main contributor in Vladivostok. However, it is worth noting that the concentrations of PAHs and NPAHs showed an overall downward trend from 1999 to 2020. An important reason for this is the cogenerations project implemented by the Far Eastern Center for Strategic Research on Fuel and Energy Complex Development in 2010. This research clarified the latest variations in PAHs and NPAHs to provide continuous observation data for future chemical reaction or model prediction research.
\end{abstract}

Keywords: persistent organic pollutants; atmospheric transport; traffic emission; Vladivostok

\section{Introduction}

Atmospheric particulate matter (PM) is a ubiquitous air pollutant that affects flora, fauna and humans. Although the concentrations of polycyclic aromatic hydrocarbons (PAHs) and nitrated polycyclic aromatic hydrocarbons (NPAH) in PM are generally much lower than those of other compounds [1,2], PAHs and NPAHs have been found to be the major components associated with carcinogens and mutagens, such as $\mathrm{BaP}$ and 6-nitrochrysene (6-NC) [3,4]. PAHs and NPAHs can easily move among ecosystems and adversely affect many organisms, including humans, due to their small size and persistence [5]. PAHs and NPAHs mainly originate from anthropogenic pyrogenic sources, such as coal combustion, vehicle emissions and biomass burning [6-8]. In fact, PAHs and NPAHs are ubiquitous in the air environment worldwide, even in remote regions, because of long-range atmospheric transportation [9-12]. In addition, PAHs in the atmosphere undergo a series of 
complex chemistry reactions that generate more PAH derivatives, for example, NPAHs not only come from incomplete combustion processes, but also form during the transformation process facilitated by photochemical reactions, hydroxyl radicals, nitrate radicals and ozone [13]. Nevertheless, 2-nitropyrene (2-NP) and 2-nitrofluoranthene (2-NFR) are produced only by heterogeneous reactions caused by free radicals [14]. Since NPAHs have higher mutagenicity and genotoxicity than PAHs $[15,16]$, species-specific information on the sources of PAHs and NPAHs is essential to assess the health risks of PAHs and NPAHs.

Vladivostok, Russia, is located in the northeast of the East Asian continent and is affected by the East Asian monsoon. According to our previous studies, the East Asian monsoon (EAM) is of great importance to atmospheric pollution in East Asia and the surrounding regions [17-19]. The warm-wet East Asian summer monsoon (EASM) and the cold-dry East Asian winter monsoon (EAWM) are two major components of the EAM. During winter, the EAWM can force Asian continental air masses to cross Mongolia, Russia, China, the Korean Peninsula and Japan to the North Pacific Ocean, which moves large numbers of contaminated air masses and dust particles [20]. In contrast, the concentration of atmospheric pollution is mainly influenced by local pollution and clean ocean air masses during the EASM [21,22]. In addition, the Free Port of Vladivostok has had a significant increase in cargo turnover, causing traffic emissions to play an important and exceptional role in air pollution over the last 20 years and to participate in the circulation system of air pollution in East Asia [23,24].

It is worth noting that the energy structure at Vladivostok has dramatically changed in recent years. The residential heating period lasts appromixmately six months every year. Our previous study in Vladivostok demonstrated that coal combustion was the major source of ambient PAHs and NPAHs in winter $[25,26]$. This study also showed that human activities and local government energy policies directly influence the concentrations and compositions of PAHs and NPAHs. Fortunately, the local government replaced coal heating energy with that of natural gas in 2010 [27]. To better understand the sources, transportation, and potential human cancer risk in Vladivostok, the PAHs and NPAHs in the PM in Vladivostok from 1999 to 2020 were investigated in this study. The objective of this work was to evaluate the pollution status (concentration, composition, main sources) and health risks of PAHs and NPAHs in the atmosphere of Vladivostok through the latest survey results from 2019 to 2020. Additionally, the long-term variability and major influencing factors of the PAHs and NPAHs in the atmosphere of Vladivostok were investigated by comparison with the previous investigation results. This study will help analyse the environmental impact of PAHs and NPAHs in the atmospheres of countries and regions located in the EAM region.

\section{Materials and Methods}

\subsection{Sample Collection}

Thirty-three total atmospheric samples were collected from December 2019 to July 2020 in the Pacific Oceanological Institute (POI), Far Eastern Branch of Russian Academy of Sciences, Vladivostok, Russia $\left(43.20^{\circ} \mathrm{N}, 131.93^{\circ} \mathrm{E}\right)$, as shown in Figure 1. According to our previous studies, Vladivostok can be influenced by domestic pollutants in summer, while can be influenced by long-range transportant pollutants in winter [28]. A high-volume air sampler (Sibata Sci. Tech. Ltd., Saitama, Japan) equipped with a quartz membrane filter (2500QAT-UP, Pallflex Products, Show Low, AZ, USA) was used to collect TSP samples at an intake flow rate of $1000 \mathrm{~L} / \mathrm{min}$. Details on the sampling periods and sample numbers are listed in Table S1. After sampling, the samples were placed in a drying cabinet for $48 \mathrm{~h}$, and then refrigerated at $-20{ }^{\circ} \mathrm{C}$ until the samples were analyzed. 


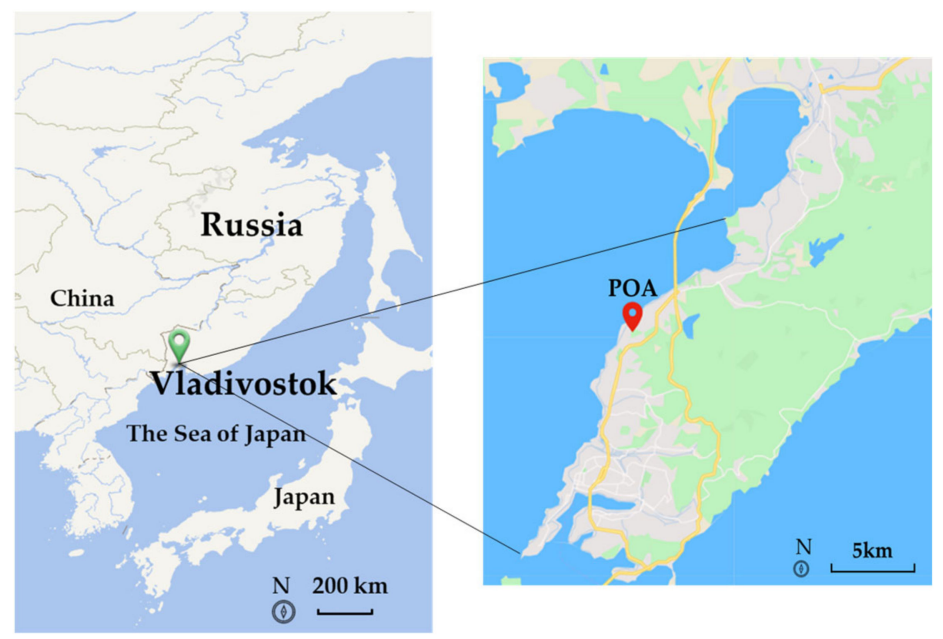

Figure 1. Sampling location of Vladivostok $\left(43.20^{\circ} \mathrm{N}, 131.93^{\circ} \mathrm{E}\right)$. Vladivostok is shown by green mark on left map and POA located in Vladivostok is shown by red mark on right map.

\subsection{PAHs and NPAHs Analysis}

Ten PAHs, including fluoranthene (FR), pyrene (Pyr), benzo[a]anthracene (BaA), chrysene $(\mathrm{Chr})$, benzo[b]fluoranthene $(\mathrm{BbF})$, benzo[ $k]$ fluoranthene $(\mathrm{BkF})$, benzo[ $a]$ pyrene $(\mathrm{BaP})$, benzo[e]pyrene (BeP), benzo[ghi]perylene (BgPe), and indeno [1,2,3-cd]pyrene (IDP) ( $\mathrm{Su}-$ pelco Park, Bellefonte, PA, USA) and six NPAHs, 2-NFR, 1-,2-NPs, 6-nitrochrysene (6-NC), 7-nitrobenz $[a]$ anthracene (7-NBaA), and 6-nitrobenzo[a]pyrene (6-NBaP) (Chiron As, Trondheim, Norway), in each PM sample were detected using our method [29]. The U.S. EPA $610 \mathrm{PAH}$ mix, including the ten target PAHs, was purchased from Dr. Ehrenstorfer GmbH (Augsburg, Germany). Two internal standards (Pyr-d10 and BaP-d12) were purchased from Wako Pure Chemicals (Osaka, Japan) and those for NPAHs (2-NFR-7-NBaA) were purcased from Chiron AS. In brief, each filter was cut into small pieces and placed in a flask. After adding Pyr-d10 and BaP-d12 (Wako Pure Chemicals, Osaka, Japan), compounds successively underwent ultrasonic extraction, washing, concentration, dilution and filtration. Then, PAHs and NPAHs in the solution were analyzed by a high-performance liquid chromatographic system with fluorescence detection (Shimadzu Inc., Kyoto, Japan). All others reagents were analytical reagent grade. The methods employed for pretreatment, quantitative determination and quality control are detailed in our previous study [30]. In addition, weather conditions, including temperature, humidity and mean wind speed during each period at Vladivostok were obtained from the National Centers for Environmental Information of National Oceanic and Atmospheric Administration (NOAA) (https:/ / www.ncei.noaa.gov / (assessed 20 May 2021)).

\subsection{Health Risk Assessment}

The toxicity equivalent factor (TEF) model is usually used for calculations of PAH carcinogenic risk based on the procedure indicated by the United States Environmental Protection Agency (USEPA) (2016) [31,32]. The development and establishment of the TEF model for PAHs could aid in the precise characterization of the carcinogenic properties of PAH mixtures. Generally, benzo[a]pyrene $(\mathrm{BaP})$ is believed to be the most toxic $\mathrm{PAH}$ and has been well-characterized toxicologically [33,34]. Numerous studies have shown that it is necessary to systematically measure $\mathrm{BaP}$ as an indicator of the PAH group, causing it to be a major health risk driver $[35,36]$. Therefore, $\mathrm{BaP}$ was designated as the reference compound in the calculation of the toxicity of PAHs using the TEF model. The toxicity equivalency $(T E Q)$ calculations were performed as follows $[37,38]$ :

$$
\begin{gathered}
T E Q_{i}=C_{i} \times T E F_{i} \\
T E Q_{\text {total }}=\sum T E Q_{i}
\end{gathered}
$$


where $T E F_{i}$ is the toxic equivalent factor of individual PAHs (Table S2).

The incremental lifetime cancer risk (ILCR) of individual PAHs and NPAHs is mainly based on animal laboratory tests and occupational epidemiological studies [39]. The ILCR estimation of PAHs and NPAHs has many uncertainties due to many factors, such as toxic synergy, in which most PAHs occur together with other carcinogenic pollutants. In addition, individuals exposed to different environments from different exposure pathways should be considered. In this study, the ILCR was assessed by applying the USEPA standard model.

The ILCRs of ingestion, dermal absorption and inhalation were calculated as follows $[40,41]$ :

$$
\begin{array}{r}
R_{i n g}=\frac{C \times C S F_{i n g} \times \sqrt[3]{\frac{B w}{70}} \times I R_{i n g} \times E F \times E D}{B W \times A T \times 10^{6}} \\
R_{i n h}=\frac{C \times C S F_{i n h} \times \sqrt[3]{\frac{B w}{70}} \times I R_{i n h} \times E F \times E D}{B W \times A T \times P E F} \\
R_{d e m}=\frac{C \times C S F_{d e m} \times \sqrt[3]{\frac{B w}{70}} \times \mathrm{SA} \times \mathrm{AF} \times \mathrm{ABS} \times E F \times E D}{B W \times A T \times 10^{6}}
\end{array}
$$

where the risk values for ingestion, inhalation and dermal exposures are expressed by $R_{\text {ing }}$, $R_{i n h}$, and $R_{d e m}$, respectively; $C$ is equal to the sum of the toxic equivalent concentrations of the 16 individual PAHs in $\mathrm{ng} / \mathrm{m}^{3}\left(C=T E Q_{P A H}\right) ; C S F_{i n g}, C S F_{i n h}$ and $C S F_{d e m}$ are the carcinogenic slope factors for ingestion, inhalation and dermal exposures, respectively, in $\mathrm{mg} / \mathrm{kg} /$ day; $B W$ is the average body weight in $\mathrm{kg} ; I R_{\text {ing }}$ is the intake rate under the ingestion exposure route in $\mathrm{mg} /$ day; $E F$ is the annual exposure frequency in day/year; $E D$ is the duration of exposure in years; $A T$ is the average lifespan in days; $I R_{i n h}$ is the rate of intake under inhalation exposure in $\mathrm{mg} /$ day; $P E F$ is the particle emission factor in $\mathrm{mg} / \mathrm{kg}$; $S A$ is the exposed area of the skin in $\mathrm{cm}^{2} ; A F$ is the skin adherence factor in $\mathrm{mg} / \mathrm{cm}^{2}$; and $A B S$ is the skin absorption factor in day $^{-1}$. The carcinogenic slope factors (CSFs) based on the cancer-causing ability of $\mathrm{BaP}$ were parameterized as $7.3,25$, and $3.85(1 /(\mathrm{mg} / \mathrm{kg} /$ day $))$ for ingestion, inhalation and dermal exposure, respectively [42]. For the related values, refer to Table S3 $[43,44]$.

The total ILCR is the summation of the three different forms of risk [45].

$$
\text { Total } I L C R=I L C R_{\text {ing }}+I L C R_{\text {inh }}+I L C R_{\text {dem }}
$$

\subsection{Statistical Analysis}

SPSS version 24.0 (IBM Corp., Armonk, NK, USA) was used for the statistical analysis of the data. T-tests were used to compare the relationships between PAHs and NPAHs in the PM samples and seasons. The correlations between PAHs, NPAHs and meteorological conditions were assessed using the Spearman correlation coefficient (two-tailed). A $p$ value of less than 0.05 indicated a statistically significant result.

\section{Results}

\subsection{Concentrations of PAHs and NPAHs}

Table 1 presents the average concentration \pm standard deviation of ten PAHs ( $\Sigma$ PAHs) and six NPAHs ( $\Sigma$ NPAHs) in winter and summer. The average concentrations of $\Sigma$ PAHs and $\Sigma$ NPAHs in winter and summer were $18.6 \pm 9.80 \mathrm{ng} / \mathrm{m}^{3}$ and $0.54 \pm 0.21 \mathrm{ng} / \mathrm{m}^{3}$, respectively. The average concentrations of $\Sigma$ NPAHs in winter and summer were $143 \pm 81.5 \mathrm{pg} / \mathrm{m}^{3}$ and $8.92 \pm 3.97 \mathrm{pg} / \mathrm{m}^{3}$, respectively. Consistent with our previous findings [26], the airborne PAH and NPAHs in winter were higher than those in summer $(\rho<0.01)$. As the most abundant PAH, BgPe contributed $21.9 \%$ and $31.5 \%$ of the total PAHs in winter and summer, respectively, in accordance with our last survey [28]. It is worth noting that the $\mathrm{BaP}$ concentration was $2.14 \pm 1.35 \mathrm{ng} / \mathrm{m}^{3}$ in winter, which still exceeded the target value $\left(1 \mathrm{ng} / \mathrm{m}^{3}\right)$ in Europe, consistent with what has been found previously. For NPAHs, 2-NFR $(30 \%)$ exhibited the highest proportion in winter, and 7-NBaA $(48 \%)$ (representing the first 
time this component had been analyzed in Vladivostok) exhibited the highest proportion in summer, because 7-NBaA can be emitted from gasoline vehicles as well as from atmospheric reactions [46]. The reason for the high 7-NBaA concentration in summer needs to be further analyzed. In both seasons, 2-NP (winter: $2 \%$, summer: $3 \%$ ) was the least abundant NPAH.

Table 1. Mean concentration \pm standard variation of PAHs and NPAHs at Vladivostok in winter and summer from 2019 to 2020.

\begin{tabular}{ccc}
\hline Compound & Winter & Summer \\
\hline FR & $1.72 \pm 0.84$ & $0.02 \pm 0.01$ \\
Pyr & $1.58 \pm 0.74$ & $0.02 \pm 0.01$ \\
BaA & $0.92 \pm 0.47$ & $0.01 \pm 0.01$ \\
Chr & $1.25 \pm 0.57$ & $0.03 \pm 0.01$ \\
BbF & $1.76 \pm 0.95$ & $0.05 \pm 0.03$ \\
BkF & $1.01 \pm 0.57$ & $0.03 \pm 0.01$ \\
BaP & $2.14 \pm 1.35$ & $0.03 \pm 0.01$ \\
BeP & $1.46 \pm 0.80$ & $0.05 \pm 0.03$ \\
BgPe & $4.08 \pm 2.33$ & $0.20 \pm 0.06$ \\
IDP & $2.68 \pm 1.55$ & $0.11 \pm 0.04$ \\
$\Sigma$ PAHs $\left(\mathrm{ng} / \mathrm{m}^{3}\right)$ & $18.6 \pm 9.80$ & $0.54 \pm 0.21$ \\
$2-\mathrm{NFR}$ & $42.5 \pm 31.3$ & $1.29 \pm 0.91$ \\
$1-\mathrm{NP}$ & $25.7 \pm 16.3$ & $0.73 \pm 0.37$ \\
2-NP & $3.28 \pm 3.81$ & $0.28 \pm 0.06$ \\
6-NC & $5.70 \pm 3.72$ & $1.12 \pm 0.58$ \\
$7-\mathrm{NBaA}$ & $39.5 \pm 24.2$ & $4.52 \pm 2.46$ \\
6-NBaP & $26.7 \pm 14.7$ & $1.42 \pm 0.55$ \\
$\Sigma \mathrm{NPAHs}\left(\mathrm{pg} / \mathrm{m}^{3}\right)$ & $143 \pm 81.5$ & $8.92 \pm 3.97$ \\
\hline
\end{tabular}

In addition, local meteorological conditions could significantly impact the PAHs and NPAHs in the atmosphere. By the Spearman correlation coefficient, the concentrations of PAHs and NPAHs were negatively correlated with temperature $(p<0.01$, as shown in Tables S4 and S5). In addition to PAHs and NPAHs with higher vapour pressures conducting gas/particle partitioning via a change in temperature [47], the changes in the main sources in winter, summer and reactivity were the main factors causing this correlation [48] (see Section 3.2 for details). However, no significant correlation with wind speed or humidity was found during the entire sampling period. This might be due to by the seasonal difference in wind speed and humidity not being significant (Tables S4 and S5).

\subsection{Main Sources of PAHs and NPAHs}

The chemical compositions of pollution provide a better understanding of pollution sources and their environmental impacts [49,50]. Many studies have used different PAH and NPAH diagnostic ratios as tracers to distinguish their diverse sources [51,52]. The latest research shows that $[\mathrm{BbF}] /([\mathrm{BbF}]+[\mathrm{BkF}])$ and $[\mathrm{IDP}] /([\mathrm{BgPe}]+[\mathrm{IDP}])$ have higher accuracy, are not affected by spatial and temporal distributions, and can be used to distinguish PAHs mainly from traffic sources or other sources [53]. As shown in Figure 2a, almost all values of $[\mathrm{BbF}] /([\mathrm{BbF}]+[\mathrm{BkF}])$ and $[\mathrm{IDP}] /([\mathrm{BgPe}]+[\mathrm{IDP}])$ were in the ranges of $0.67-0.81$ and $0.26-0.49$, respectively. These results suggest that vehicle emissions were the main source of PAHs and NPAHs in Vladivostok from 2019 to 2020. On the other hand, $[\mathrm{BaP}] /[\mathrm{BgPe}]$ can be used to distinguish PAHs and NPAHs from traffic sources $(<0.6)$ or coal combustion s (>0.6) [54]. The $[\mathrm{BaP}] /([\mathrm{BaP}]+[\mathrm{BeP}])$ ratio has been used to assess the contributions of local sources to atmospheric PAHs and NPAHs (>0.6) [55]. As shown in Figure $2 b$, most of the $[\mathrm{BaP}] /[\mathrm{BgPe}]$ ratios were less than 0.6, which also showed that traffic sources are the main contributors to airborne PAHs and NPAHs in Vladivostok. However, some of the $[\mathrm{BaP}] /[\mathrm{BgPe}]$ ratios in winter were close to or higher than 0.6, indicating that coal combustion is still a nonnegligible contributor in winter. The values of $[\mathrm{BaP}] /([\mathrm{BaP}]+[\mathrm{BeP}])$ mainly varied between 0.52 and 0.65 in winter, indicating a dominant 
contribution from long-range atmospheric transport. According to other studies, the contaminated air mass may come from Northeast China and Mongolia [28,56]. In summer, almost all $[\mathrm{BaP}] /([\mathrm{BaP}]+[\mathrm{BeP}])$ ratios were below 0.5 , indicating that local emissions might contribute to PAHs and NPAHs at Vladivostok. As in our previous study $[1,11,28]$, this may be a reason for the decrease in $[\mathrm{BaP}] /([\mathrm{BaP}]+[\mathrm{BeP}])$, since the air mass in summer mainly comes from the Vladivostok port.
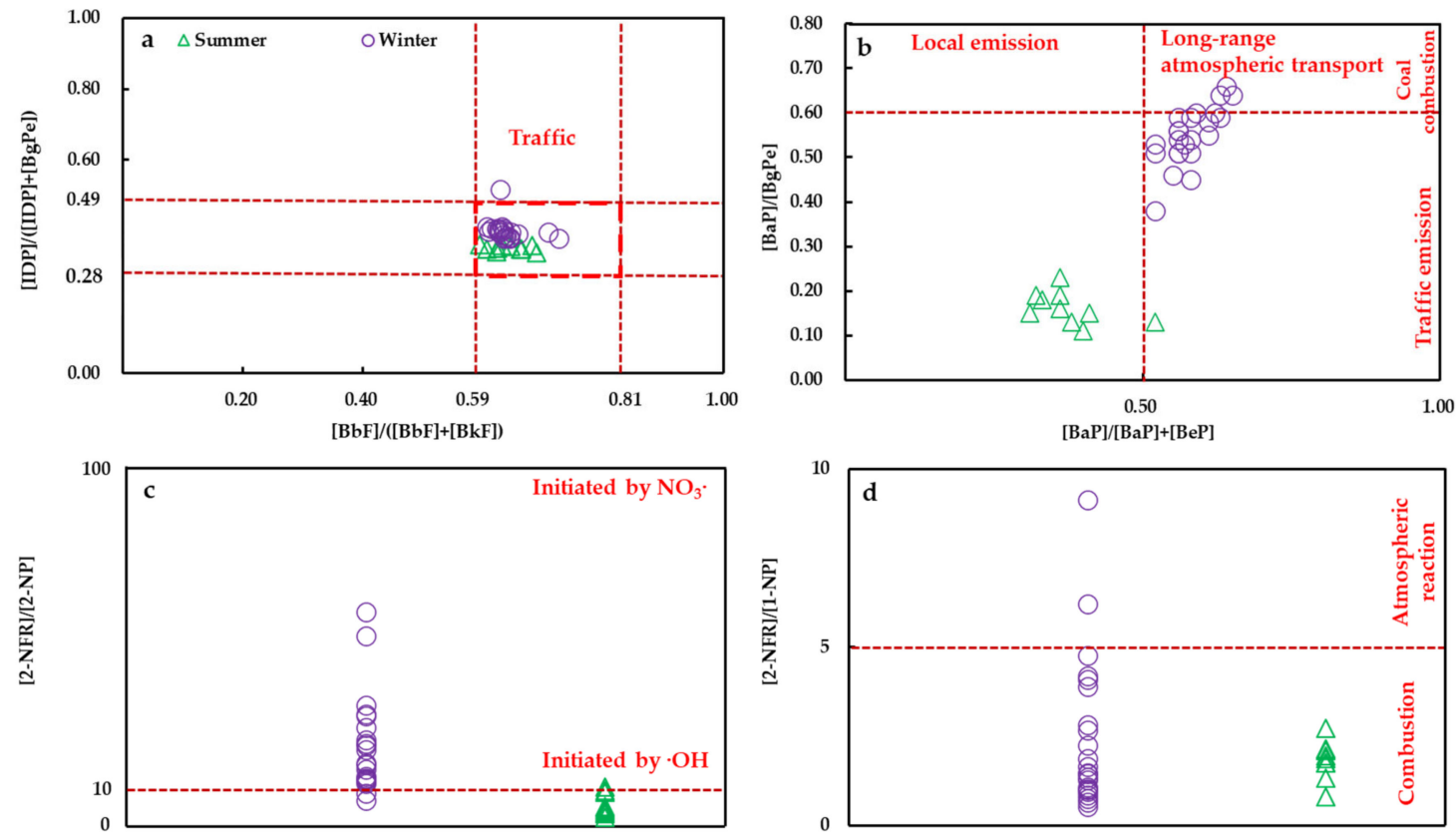

Figure 2. The diagnostic ratios of PAHs and NPAHs at Vladivostok in both seasons and their specific sources. (a) diagnostic $[\mathrm{BbF}] /([\mathrm{BbF}]+[\mathrm{BkF}])$ and $[\mathrm{IDP}] /([\mathrm{BgPe}]+[\mathrm{IDP}])$ ratios from traffic emission; $(\mathbf{b})$ diagnostic $[\mathrm{BaP}] /([\mathrm{BaP}]+[\mathrm{BeP}])$ and $[\mathrm{BaP}] /[\mathrm{BgPe}]$ ratios from local emission, long-range transportation, traffic emission, coal combustion; (c) diagnostic [2-NFR]/[2-NP] ratios from gas-phase chemical reaction, $(\mathrm{d})$ diagnostic $[2-\mathrm{NFR}] /[1-\mathrm{NP}]$ ratios from combustion or atmospheric reaction.

Additionally, NPAHs in ambient air are either from primary emissions or from secondary formations. Laboratory studies and field observations have shown that 2-NP and 2-NFR are formed during the photochemical transformation of emitted PYR and FR by atmospheric oxidants [57-59], while 1-NP is emitted from vehicle exhausts [60,61]. When the concentration ratio of [2-NFR]/[2-NP] is approximately 10, 2-NP and 2-NFR are from the photochemical by the hydroxyl radical pathways, whereas when the [2-NFR]/[2-NP] concentration ratios are approximately 100, 2-NP and 2-NFR are from the reaction for gasphase nitrate radical reactions [62,63]. Figure $2 \mathrm{c}$ reveals that most of the concentration ratios of [2-NFR]/[2-NP] approached 10 in both seasons, indicating that 2-NP and 2-NFR were mainly formed by hydroxyl radical-initiated photochemical reactions. [2-NFR]/[1-NP] can be divided into airborne NPAHs that are mainly generated from combustion (fresh particles, value $<5$ ) or atmospheric reactions (ageing particles, value $>5$ ) [64]. As shown in Figure 2d, almost all ratios were less than or close to 5, indicating that the NPAHs except 2-NP and 2-NFR were mainly from the incomplete combustion of fossil fuels and biomass in both seasons.

\subsection{Health Effects of PAHs and NPAHs}

\subsubsection{Toxic Equivalency Relative to BaP (TEQ)}

Table 2 presents the results obtained from the TEQ for total and individual PAHs and NPAHs (except 2-NP, 7-NBaA, 6-NBaP due to a lack of toxic equivalent factors data) in winter and summer. In winter, the average TEQ of the total PAHs and NPAHs( $\Sigma$ PAHs $+\Sigma$ NPAHs) was $2.90 \mathrm{ng} / \mathrm{m}^{3}$. During summer, the average TEQ of ( $\Sigma$ PAHs $+\Sigma$ NPAHs $)$ was $0.06 \mathrm{ng} / \mathrm{m}^{3}$. 
The average TEQ concentration of ( $\Sigma$ PAHs $+\Sigma$ NPAHs) in winter was approximately three times higher than the European Union standard $\left(1 \mathrm{ng} / \mathrm{m}^{3}\right)$ [65], indicating that the atmosphere in Vladivostok is still seriously contaminated in winter. These results also showed that $\mathrm{BkF}, \mathrm{BbF}, \mathrm{BaP}$ and IDP were the dominant components of the total average TEQ concentrations in both seasons (winter: 93\%, summer: 76\%). The International Agency for Research on Cancer (IARC) has classified $\mathrm{BaP}$ as a probable carcinogen and $\mathrm{BkF}, \mathrm{BbF}$, and IDP as possible carcinogens to humans. The concentration of TEQ in NPAHs was mainly determined by 6-NC because the carcinogenic effect of 6-NC is much higher than that of $\mathrm{BaP}[66]$, and the proportions of [6-NC]/[NPAHs] in winter and summer were $95 \%$ and $99 \%$, respectively.

Table 2. Toxic equivalent concentrations relative to BaP of PAHs and NPAHs (except 2-NP, 7-NBaA, 6-NBaP) at Vladivostok in winter and summer from 2019 to 2020.

\begin{tabular}{|c|c|c|c|}
\hline & & Winter & Summer \\
\hline \multirow{11}{*}{ PAHs $\left(\mathrm{ng} / \mathrm{m}^{3}\right)$} & FR & 0.002 & 0.00002 \\
\hline & Pyr & 0.002 & 0.00002 \\
\hline & $\mathrm{BaA}$ & 0.092 & 0.00133 \\
\hline & Chr & 0.012 & 0.00028 \\
\hline & $\mathrm{BbF}$ & 0.176 & 0.00482 \\
\hline & $\mathrm{BkF}$ & 0.101 & 0.00256 \\
\hline & $\mathrm{BaP}$ & 2.138 & 0.02992 \\
\hline & $\mathrm{BeP}$ & 0.003 & 0.00011 \\
\hline & $\mathrm{BgPe}$ & 0.041 & 0.00198 \\
\hline & IDP & 0.268 & 0.01078 \\
\hline & $\Sigma$ PAHs & 2.84 & 0.05 \\
\hline \multirow{4}{*}{ NPAHs $\left(\mathrm{pg} / \mathrm{m}^{3}\right)$} & 2-NFR & 0.425 & 0.01292 \\
\hline & 1-NP & 2.571 & 0.07282 \\
\hline & 6-NC & 57.012 & 11.24783 \\
\hline & $\Sigma$ NPAHs & 60.01 & 11.33 \\
\hline Total & $\mathrm{ng} / \mathrm{m}^{3}$ & 2.90 & 0.06 \\
\hline
\end{tabular}

\subsubsection{ILCR Assessment}

To further understand the health risks for the different sexes, we analyzed the ILCR and total accumulated risks. The ILCR collectively accounts for the integrated lifetime risks of exposure to airborne PAHs and NPAHs through direct ingestion, dermal contact, and inhalation. The USEPA recommends an acceptable carcinogenic risk value of $1.0 \times 10^{-6}$, while there is a higher probability of cancer occurring from PAH and NPAH exposure if the value exceeds $1.0 \times 10^{-4}$ [67-70]. As shown in Table 3, the total ILCRs of PAHs and NPAHs from the three exposure routes were exhibited the following order: ingestion exposure (male: winter: $1.36 \times 10^{-5}$, summer: $2.96 \times 10^{-7}$; female: winter: $1.23 \times 10^{-5}$, summer: $2.68 \times 10^{-7}$ ) > dermal exposure (male: winter: $3.71 \times 10^{-6}$, summer: $8.10 \times 10^{-8}$; female: winter: $2.68 \times 10^{-7}$, summer: $7.33 \times 10^{-8}$ ) > inhalation exposure (male: winter: $6.83 \times 10^{-9}$, summer: $1.49 \times 10^{-10}$; female: winter: $6.19 \times 10^{-9}$, summer: $1.35 \times 10^{-10}$ ) In winter, of the three exposure routes, ingestion exposure and dermal exposure exceeded the acceptable carcinogenic risk value. Compared with other studies [71,72], these results showed that people living in Vladivistok were exposed to PAHs via ingestin and dermal contact at a level posing a potential risk to their health. 
Table 3. The ILCR of PAHs and NPAHs according three exposure pathways at Vladivostok in winter and summer from 2019 to 2020.

\begin{tabular}{cccc}
\hline \multirow{2}{*}{ Winter $(n=23)$} & Male & Female \\
& Ingestion & $1.36 \times 10^{-5}$ & $1.23 \times 10^{-5}$ \\
& Inhalation & $6.83 \times 10^{-9}$ & $6.19 \times 10^{-9}$ \\
& Dermal & $3.71 \times 10^{-6}$ & $3.36 \times 10^{-6}$ \\
& Total & $1.73 \times 10^{-5}$ & $1.57 \times 10^{-5}$ \\
& & & $2.68 \times 10^{-7}$ \\
Summer $(n=10)$ & Ingestion & $2.96 \times 10^{-7}$ & $1.35 \times 10^{-10}$ \\
& Inhalation & $1.49 \times 10^{-10}$ & $7.33 \times 10^{-8}$ \\
& Dermal & $8.10 \times 10^{-8}$ & $3.41 \times 10^{-7}$ \\
\hline
\end{tabular}

Numerically, the calculated male's ILCRs were higher than the female's ILCRs in both seasons, as shown in Table 3. In fact, the ILCRs for males remained on the same order of magnitude as the female's ILCRs. The slight difference may be due to the lower body weight and the greater sensitivity to toxic substances of females [40].

The ILCRs of PAHs and NPAHs from all exposure routes were much higher in winter than in summer. The ranges of the ILCR of PAHs and NPAHs from all exposure routes were $6.19 \times 10^{-9}-1.36 \times 10^{-5}$ and $1.35 \times 10^{-10}-2.96 \times 10^{-7}$ in winter and summer, respectively. In winter, the values of the ILCRs of PAHs and NPAHs exceeded the acceptable carcinogenic risk value of USEPA, indicating that long-term residents in Vladivostok are exposed to potential carcinogenic risks. Likewise, the treatment of pollution sources in winter is still an urgent task.

\subsection{Long-Term Trends and Variations in $\Sigma 9 P A H s$ and 1-NP}

Figure 3 presents the temporal variations in $\Sigma 9 \mathrm{PAHs}$ (except BeP) and 1-NP during winter and summer from 1999 to 2020 . These compunds have been analyzed since 1999 . The $\Sigma 9 P A H s$ concentration varied from $17.0 \mathrm{ng} / \mathrm{m}^{3}$ (2019) to $34.0 \mathrm{ng} / \mathrm{m}^{3}$ (1999) during winter and $0.50 \mathrm{ng} / \mathrm{m}^{3}$ (2020) to $3.10 \mathrm{ng} / \mathrm{m}^{3}$ (2017) in summer. The 1-NP concentration varied from $24.0 \mathrm{pg} / \mathrm{m}^{3}$ to $114 \mathrm{pg} / \mathrm{m}^{3}$ in winter and $6.00 \mathrm{pg} / \mathrm{m}^{3}$ to $0.70 \mathrm{pg} / \mathrm{m}^{3}$ in summer. In a comparison to the concentration of $\Sigma 9 \mathrm{PAHs}$ in 1999, that of 2019-2020 showed a singnificant decline: $50 \%$ in winter and $57 \%$ in summer. The concentration of 1 -NP decreased by $77 \%$ in winter and $83 \%$ in summer from that in 1999 . Nevertheles, there was a significant increasing trend during both seasons in 2010 and summer in 2017. Based on our previous research, according to the Asia Pacific Economic Cooperation (APEC) meeting in 2012, many infrastructure construction projects were under construction in Russia from 2007 to 2012, which may have led to an increase in the concentration of PAHs [25]. In addition, the Russia-China naval activities in the Sea of Japan and the Sea of Okhotsk in September 2017 [73] may have led to an increase in $\sum$ PAHs, and the impact of these emergencies on PAHs cannot be ignored.

For the control of air pollution, the Russian government has taken many positive steps. Among them, the cogeneration (combined heat and power) project promoted by The Far Eastern Center for Strategic Research on Fuel and Energy Complex Development in 2010 may promote a reduction in PAHs concentrations, and has played an important role in the recent improvement in the atmospheric environment [24,74]. 

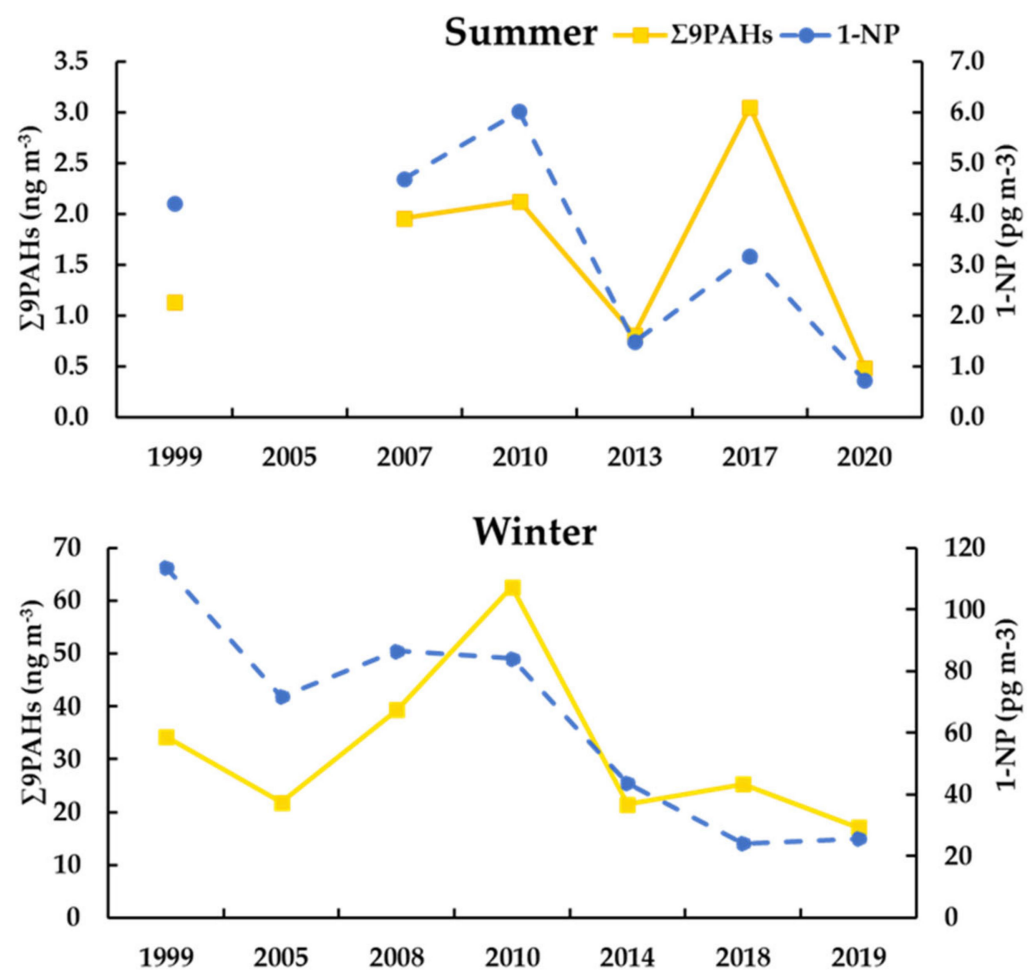

Figure 3. Yearly variations in $\sum 9 \mathrm{PAHs}$ (except BeP) and 1-NP at Vladivostok in summer and winter.

\section{Conclusions}

Vladivostok is an important port city in the Far East of Russia, and participates in the atmospheric cycle of air pollutants in East Asia. We have sequentially conducted investigations and research in Vladivostok for approximately 20 years. In the study, three kinds of target NPAHs were added, and 7-NBaA showed the highest level in summer. Additionally, the risk assessment of different PAH and NPAH exposure routes was carried out first, and it was noted that ingestion and dermal exposure were important exposure routes endangering the health of residents. In this study, the concentrations of PAHs and NPAHs decreased significantly compared with those in 1999. This is because of the cogeneration project implemented by the Far Eastern Center for Strategic Research on Fuel and Energy Complex Development in 2010. However, the concentrations of atmospheric PAHs and NPAHs in winter are still worthy of attention because the average TEQ concentration of $\Sigma$ PAHs $+\Sigma$ NPAHs was still approximately three times higher than the value of the European Union standard. The data obtained from this study not only play a role in helping the formulation of atmospheric environmental protection policies in Vladivostok, but also provide basic data for understanding the lon g-range transportation of air pollutants in the East Asian monsoon region.

Supplementary Materials: The following supporting information can be downloaded at: https: / / www.mdpi.com/article/10.3390/ijerph19052878/s1, Table S1: Sampling periods and sample numbers; Table S2: Toxic equivalent factor (TEF) of polycyclic aromatic hydrocarbons (PAHs) and nitro-PAHs (NPAHs); Table S3: Parameters used for the estimation of the incremental lifetime cancer risks (ILCRs); Table S4. Daily weather conditions in each sample at Vladivostok; Table S5. Spearman correlation coefficient (two-tailed) of each PAHs and NPAHs with weather condition during sampling period.

Author Contributions: N.T. designed the sampling work, and performed the PAH analyses for particulate matters; N.T., L.Z., A.N., V.F.M., H.Z., X.Z., Y.W. and P.B. collected samples and conducted monitoring work; Y.W. analyzed the PAHs; Y.W. and X.Z. performed statistical analysis; N.T. and L.Z. gave recommendations to the paper; K.H. and S.N. reviewed and commented during the creation 
process of the paper; Y.W. and N.T. wrote the paper. All authors have read and agreed to the published version of the manuscript.

Funding: This work was supported by the Environment Research and Technology Development Fund (5-1951) of the Environmental Restoration and Conservation Agency of Japan; the Bilateral Open Partnership Joint Research Projects of the Japan Society for the Promotion of Science, Japan (JPJSBP120219914); the CHOZEN Project of Kanazawa University, Japan; and the cooperative research programs of Institute of Nature and Environmental Technology, Kanazawa University, Japan.

Institutional Review Board Statement: Not applicable.

Informed Consent Statement: Not applicable.

Data Availability Statement: Data is contained within the article or Supplementary Material. The data presented in this study are available in Supplementary Material.

Acknowledgments: We thank the National Oceanic and Atmospheric Administration Air Resources Laboratory for providing the HYSPLIT 4 model (window-based). The authors acknowledge the Institute of Nature and Environmental Technology, Kanazawa University for the provision of the scientific data used in this publication (https:/ / ki-net.db.kanazawa-u.ac.jp/ (accessed 20 May 2021)).

Conflicts of Interest: The authors declare no conflict of interest.

\section{References}

1. Yang, L.; Zhou, Q.Y.; Zhang, H.; Zhang, X.; Xing, W.L.; Wang, Y.; Bai, P.C.; Yamauchi, M.; Chohji, T.; Zhang, L.L.; et al. Atmospheric Behaviour of Polycyclic and Nitro-Polycyclic Aromatic Hydrocarbons and Water-Soluble Inorganic Ions in Winter in Kirishima, a Typical Japanese Commercial City. Int. J. Environ. Res. Public Health 2021, 18, 688. [CrossRef] [PubMed]

2. ChooChuay, C.; Pongpiachan, S.; Tipmanee, D.; Deelaman, W.; Suttinun, O.; Wang, Q.; Xing, L.; Li, G.; Han, Y.; Palakun, J.; et al. Long-Range Transboundary Atmospheric Transport of Polycyclic Aromatic Hydrocarbons, Carbonaceous Compositions, and Water-Soluble Ionic Species in Southern Thailand. Aerosol Air Qual. Res. 2020, 20, 1591-1606. [CrossRef]

3. Wang, M.; Jia, S.; Lee, S.H.; Chow, A.; Fang, M. Polycyclic Aromatic Hydrocarbons (PAHs) in Indoor Environments Are Still Imposing Carcinogenic Risk. J. Hazard. Mater. 2021, 409, 124531. [CrossRef] [PubMed]

4. $\quad$ Rahmatinia, T.; Kermani, M.; Farzadkia, M.; Nicknam, M.H.; Soleimanifar, N.; Mohebbi, B.; Jafari, A.J.; Shahsavani, A.; Fanaei, F. Potential Cytotoxicity of PM2.5-Bound PAHs and Toxic Metals Collected from Areas with Different Traffic Densities on Human Lung Epithelial Cells (A549). J. Environ. Health Sci. Eng. 2021, 19, 1701-1712. [CrossRef]

5. Rowe, G.T.; Fernando, H.; Elferink, C.; Ansari, G.A.S.; Sullivan, J.; Heathman, T.; Quigg, A.; Petronella Croisant, S.; Wade, T.L.; Santschi, P.H. Polycyclic Aromatic Hydrocarbons (PAHs) Cycling and Fates in Galveston Bay, Texas, USA. PLoS ONE 2020, 15, e0243734. [CrossRef] [PubMed]

6. Wang, J.; Li, X.; Jiang, N.; Zhang, W.; Zhang, R.; Tang, X. Long Term Observations of PM 2.5 -Associated PAHs: Comparisons between Normal and Episode Days. Atmos. Environ. 2015, 104, 228-236. [CrossRef]

7. Yadav, A.; Behera, S.N.; Nagar, P.K.; Sharma, M. Spatio-Seasonal Concentrations, Source Apportionment and Assessment of Associated Human Health Risks of PM2.5-Bound Polycyclic Aromatic Hydrocarbons in Delhi, India. Aerosol Air Qual. Res. 2020, 20, 2805-2825. [CrossRef]

8. $\quad$ Alves, C.A.; Vicente, A.M.; Custódio, D.; Cerqueira, M.; Nunes, T.; Pio, C.; Lucarelli, F.; Calzolai, G.; Nava, S.; Diapouli, E.; et al. Polycyclic Aromatic Hydrocarbons and Their Derivatives (Nitro-PAHs, Oxygenated PAHs, and Azaarenes) in PM 2.5 from Southern European Cities. Sci. Total Environ. 2017, 595, 494-504. [CrossRef]

9. Lammel, G. Long-Range Atmospheric Transport of Polycyclic Aromatic Hydrocarbons Is Worldwide Problem-Results from Measurements at Remote Sites and Modelling. Acta Chim. Slov. 2015, 62, 729-735. [CrossRef]

10. Zhang, L.L.; Yang, L.; Zhou, Q.Y.; Zhang, X.; Xing, W.L.; Zhang, H.; Toriba, A.; Hayakawa, K.; Tang, N. Impact of the COVID-19 Outbreak on the Long-Range Transport of Particulate PAHs in East Asia. Aerosol Air Qual. Res. 2020, 20, 2035-2046. [CrossRef]

11. Yang, L.; Zhang, L.L.; Zhang, H.; Zhou, Q.Y.; Zhang, X.; Xing, W.L.; Takami, A.; Sato, K.; Shimizu, A.; Yoshino, A.; et al. Comparative Analysis of PM2.5-Bound Polycyclic Aromatic Hydrocarbons (PAHs), Nitro-PAHs (NPAHs), and Water-Soluble Inorganic Ions (WSIIs) at Two Background Sites in Japan. Int. J. Environ. Res. Public Health 2020, 17, 8224. [CrossRef]

12. Zhang, H.; Zhang, L.L.; Yang, L.; Zhou, Q.Y.; Zhang, X.; Xing, W.L.; Hayakawa, K.; Toriba, A.; Tang, N. Impact of COVID-19 Outbreak on the Long-Range Transport of Common Air Pollutants in KUWAMS. Chem. Pharm. Bull. 2021, 69, 237-245. [CrossRef]

13. Keyte, I.J.; Harrison, R.M.; Lammel, G. Chemical Reactivity and Long-Range Transport Potential of Polycyclic Aromatic Hydrocarbons-A Review. Chem. Soc. Rev. 2013, 42, 9333. [CrossRef]

14. Arey, J.; Zielinska, B.; Atkinson, R.; Winer, A.M.; Ramdahl, T.; Pitts, J.N. The formation of nitro-PAH from the gas-phase reactions of fluoranthene and pyrene with the $\mathrm{OH}$ radical in the presence of NOx. Atmos. Environ. 1986, 12, 2339-2345. [CrossRef] 
15. Durant, J.L.; Busby, W.F.; Lafleur, A.L.; Penman, B.W.; Crespi, C.L. Human Cell Mutagenicity of Oxygenated, Nitrated and Unsubstituted Polycyclic Aromatic Hydrocarbons Associated with Urban Aerosols. Mutat. Res./Genet. Toxicol. 1996, 371, 123-157. [CrossRef]

16. Maselli, B.S.; Cunha, V.; Lim, H.; Bergvall, C.; Westerholm, R.; Dreij, K.; Watanabe, T.; Cardoso, A.A.; Pozza, S.A.; Umbuzeiro, G.A.; et al. Similar Polycyclic Aromatic Hydrocarbon and Genotoxicity Profiles of Atmospheric Particulate Matter from Cities on Three Different Continents. Environ. Mol. Mutagen. 2020, 61, 560-573. [CrossRef]

17. Tang, N.; Sato, K.; Tokuda, T.; Tatematsu, M.; Hama, H.; Suematsu, C.; Kameda, T.; Toriba, A.; Hayakawa, K. Factors Affecting Atmospheric 1-, 2-Nitropyrenes and 2-Nitrofluoranthene in Winter at Noto Peninsula, a Remote Background Site, Japan. Chemosphere 2014, 107, 324-330. [CrossRef] [PubMed]

18. Zhang, L.L.; Yang, L.; Bi, J.; Liu, Y.; Toriba, A.; Hayakawa, K.; Nagao, S.; Tang, N. Characteristics and Unique Sources of Polycyclic Aromatic Hydrocarbons and Nitro-Polycyclic Aromatic Hydrocarbons in PM2.5 at a Highland Background Site in Northwestern China. Environ. Pollut. 2021, 274, 116527. [CrossRef] [PubMed]

19. Zhang, X.; Zhang, L.L.; Yang, L.; Zhou, Q.Y.; Xing, W.L.; Toriba, A.; Hayakawa, K.; Wei, Y.; Tang, N. Characteristics of Polycyclic Aromatic Hydrocarbons (PAHs) and Common Air Pollutants at Wajima, a Remote Background Site in Japan. Int. J. Environ. Res. Public Health 2020, 17, 957. [CrossRef] [PubMed]

20. He, S.; Gao, Y.; Li, F.; Wang, H.; He, Y. Impact of Arctic Oscillation on the East Asian Climate: A Review. Earth-Sci. Rev. 2017, 164, 48-62. [CrossRef]

21. Hayakawa, K.; Tang, N.; Kameda, T.; Toriba, A. Atmospheric Behaviors of Polycyclic Aromatic Hydrocarbons in East Asia. Genes Environ. 2014, 36, 152-159. [CrossRef]

22. Zhou, Q.Y.; Zhang, L.L.; Yang, L.; Zhang, X.; Xing, W.L.; Hu, M.; Chen, B.; Han, C.; Toriba, A.; Hayakawa, K.; et al. Long-Term Variability of Inorganic Ions in TSP at a Remote Background Site in Japan (Wajima) from 2005 to 2015. Chemosphere 2021, 264, 128427. [CrossRef] [PubMed]

23. Gudkova, E.V.; Zaostrovskikh, E.A. Development of Sea Ports in the Far East of Russia: Economic Aspect. IOP Conf. Ser. Earth Environ. Sci. 2021, 666, 062040. [CrossRef]

24. Giyasov, B.; Giyasov, R. Factors Affecting the Environment of the City of Vladivostok. E3S Web Conf. 2021, 244, 01008. [CrossRef]

25. Hayakawa, K.; Tang, N.; Nagato, E.; Toriba, A.; Lin, J.-M.; Zhao, L.; Zhou, Z.; Qing, W.; Yang, X.; Mishukov, V.; et al. Long-Term Trends in Urban Atmospheric Polycyclic Aromatic Hydrocarbons and Nitropolycyclic Aromatic Hydrocarbons: China, Russia, and Korea from 1999 to 2014. IOP Conf. Ser. Earth Environ. Sci. 2020, 17, 431. [CrossRef] [PubMed]

26. Tang, N.; Hattori, T.; Taga, R.; Igarashi, K.; Yang, X.; Tamura, K.; Kakimoto, H.; Mishukov, V.F.; Toriba, A.; Kizu, R.; et al. Polycyclic Aromatic Hydrocarbons and Nitropolycyclic Aromatic Hydrocarbons in Urban Air Particulates and Their Relationship to Emission Sources in the Pan-Japan Sea Countries. Atmos. Environ. 2005, 39, 5817-5826. [CrossRef]

27. Popov, S. Comparison of Russian and Japanese Patterns for Energy Use: Implications for Business and Policy; The Institute of Energy Economics: Tokyo, Japan, 2012; p. 13.

28. Yang, L.; Zhang, L.L.; Chen, L.; Han, C.; Akutagawa, T.; Endo, O.; Yamauchi, M.; Neroda, A.; Toriba, A.; Tang, N. Polycyclic Aromatic Hydrocarbons and Nitro-Polycyclic Aromatic Hydrocarbons in Five East Asian Cities: Seasonal Characteristics, Health Risks, and Yearly Variations. Environ. Pollut. 2021, 287, 117360. [CrossRef]

29. Tang, N.; Toriba, A.; Kizu, R.; Hayakawa, K. Improvement of an Automatic HPLC System for Nitropolycyclic Aromatic Hydrocarbons: Removal of an Interfering Peak and Increase in the Number of Analytes. Anal. Sci. 2003, 19, 249-253. [CrossRef]

30. Zhang, L.L.; Tokuda, T.; Yang, L.; Zhou, Q.Y.; Zhang, X.; Xing, W.L.; Wu, Q.; Zhou, Z.; Chen, R.; Kameda, T.; et al. Characteristics and Health Risks of Particulate Polycyclic Aromatic Hydrocarbons and Nitro-Polycyclic Aromatic Hydrocarbons at Urban and Suburban Elementary Schools in Shanghai, China. Asian J. Atmos. Environ. 2019, 13, 10. [CrossRef]

31. Minnesota Department of Health. Guidance for Evaluating the Cancer Potency of Polycyclic Aromatic Hydrocarbon (PAH) Mixtures in Environmental Samples; Environmental Health Division, Environmental Surveillance and Assessment Section, Minnesota Department of Health: St. Paul, MN, USA, 2016.

32. Zhang, L.L.; Morisaki, H.; Wei, Y.; Li, Z.; Yang, L.; Zhou, Q.Y.; Zhang, X.; Xing, W.L.; Hu, M.; Shima, M.; et al. Characteristics of Air Pollutants inside and Outside a Primary School Classroom in Beijing and Respiratory Health Impact on Children. Environ. Pollut. 2019, 255, 113147. [CrossRef]

33. Brune, H.; Deutsch-Wenzel, R.P.; Habs, M.; Ivankovic, S.; Schmhl, D. Investigation of the Tumorigenic Response to Benzo(a)Pyrene in Aqueous Caffeine Solution Applied Orally to Sprague-Dawley Rats. J. Cancer Res. Clin. Oncol. 1981, 102, 153-157. [CrossRef] [PubMed]

34. Tseng, Y.-H.; Chen, Y.-C.; Yu, A.L.; Yu, J. Benzo[a]Pyrene Induces Fibrotic Changes and Impairs Differentiation in Lung Stem Cells. Ecotoxicol. Environ. Saf. 2021, 210, 111892. [CrossRef]

35. Bieser, J.; Aulinger, A.; Matthias, V.; Quante, M. Impact of emission reductions between 1980 and 2020 on atmospheric benzo [a] pyrene concentrations over Europe. Water Air Soil Pollut. 2012, 223, 1393-1414. [CrossRef]

36. Jung, K.H.; Yan, B.; Chillrud, S.N.; Perera, F.P.; Whyatt, R.; Camann, D.; Kinney, P.L.; Miller, R.L. Assessment of Benzo(a)PyreneEquivalent Carcinogenicity and Mutagenicity of Residential Indoor versus Outdoor Polycyclic Aromatic Hydrocarbons Exposing Young Children in New York City. Int. J. Environ. Res. Public Health 2010, 7, 1889-1900. [CrossRef] [PubMed] 
37. Zhang, X.; Yang, L.; Zhang, H.; Xing, W.L.; Wang, Y.; Bai, P.C.; Zhang, L.L.; Hayakawa, K.; Toriba, A.; Wei, Y.; et al. Assessing Approaches of Human Inhalation Exposure to Polycyclic Aromatic Hydrocarbons: A Review. Int. J. Environ. Res. Public Health 2021, 18, 3124. [CrossRef] [PubMed]

38. Yang, L.; Zhang, H.; Zhang, X.; Xing, W.L.; Wang, Y.; Bai, P.C.; Zhang, L.L.; Hayakawa, K.; Toriba, A.; Tang, N. Exposure to Atmospheric Particulate Matter-Bound Polycyclic Aromatic Hydrocarbons and Their Health Effects: A Review. Int. J. Environ. Res. Public Health 2021, 18, 2177. [CrossRef]

39. Valli, H. Cancer Risk Assessment, Indicators, and Guidelines for Polycyclic Aromatic Hydrocarbons in the Ambient Air. Environ. Health Perspect. 2002, 110, 38. [CrossRef]

40. Chen, S.C.; Liao, C.M. Health risk assessment on human exposed to environmental polycyclic aromatic hydrocarbons pollution sources. Sci. Total Environ. 2006, 366, 112-123. [CrossRef]

41. De Miguel, E.; Iribarren, I.; Chacón, E.; Ordoñez, A.; Charlesworth, S. Risk-Based Evaluation of the Exposure of Children to Trace Elements in Playgrounds in Madrid (Spain). Chemosphere 2007, 66, 505-513. [CrossRef]

42. Peng, C.; Chen, W.; Liao, X.; Wang, M.; Ouyang, Z.; Jiao, W.; Bai, Y. Polycyclic Aromatic Hydrocarbons in Urban Soils of Beijing: Status, Sources, Distribution and Potential Risk. Environ. Pollut. 2011, 159, 802-808. [CrossRef]

43. Russtat. 2019 Database. 2019. Available online: https://knoema.com/atlas/Russian-Federation/topics/Health?origin=cn. knoema.com (accessed on 20 December 2021).

44. Chen, J.W.; Wang, S.L.; Hsieh, D.P.; Yang, H.H.; Lee, H.L. Carcinogenic potencies of polycyclic aromatic hydrocarbons for back-door neighbors of restaurants with cooking emissions. Sci. Total Environ. 2012, 417-418, 68-75. [CrossRef] [PubMed]

45. Liu, J.L.; Zhang, J.; Liu, F.; Zhang, L.L. Polycyclic Aromatic Hydrocarbons in Surface Sediment of Typical Estuaries and the Spatial Distribution in Haihe River Basin. Ecotoxicology 2014, 23, 486-494. [CrossRef] [PubMed]

46. Pham, C.T.; Kameda, T.; Toriba, A.; Hayakawa, K. Polycyclic Aromatic Hydrocarbons and Nitropolycyclic Aromatic Hydrocarbons in Particulates Emitted by Motorcycles. Environ. Pollut. 2013, 183, 175-183. [CrossRef]

47. Zhang, L.L.; Yang, L.; Zhou, Q.Y.; Zhang, X.; Xing, W.L.; Wei, Y.; Hu, M.; Zhao, L.; Toriba, A.; Hayakawa, K.; et al. Size Distribution of Particulate Polycyclic Aromatic Hydrocarbons in Fresh Combustion Smoke and Ambient Air: A Review. J. Environ. Sci. 2020, 88, 370-384. [CrossRef]

48. Tang, N.; Tokuda, T.; Izzaki, A.; Tamura, K.; Ji, R.; Zhang, X.; Dong, L.; Kameda, T.; Toriba, A.; Hayakawa, K. Recent Changes in Atmospheric Polycyclic Aromatic Hydrocarbons (PAHs) and Nitropolycyclic Aromatic Hydrocarbons (NPAHs) in Shenyang, China. Environ. Forensics 2011, 12, 342-348. [CrossRef]

49. Li, C.K.; Kamens, R.M. The Use of Polycyclic Aromatic Hydrocarbons as Source Signatures in Receptor Modeling. Atmos. Environt. Part A Gen. Top. 1993, 27, 523-532. [CrossRef]

50. Venkataraman, C.; Friedlander, S.K. Size Distributions of Polycyclic Aromatic Hydrocarbons and Elemental Carbon. 2. Ambient Measurements and Effects of Atmospheric Processes. Environ. Sci. Technol. 1994, 28, 563-572. [CrossRef]

51. Wang, W.; Ding, X.; Turap, Y.; Tursun, Y.; Abulizi, A.; Wang, X.; Shao, L.; Talifu, D.; An, J.; Zhang, X.; et al. Distribution, Sources, Risks, and Vitro DNA Oxidative Damage of PM2.5-Bound Atmospheric Polycyclic Aromatic Hydrocarbons in Urumqi, NW China. Sci. Total Environ. 2020, 739, 139518. [CrossRef] [PubMed]

52. He, J.; Zielinska, B.; Balasubramanian, R. Composition of Semi-Volatile Organic Compounds in the Urban Atmosphere of Singapore: Influence of Biomass Burning. Atmos. Chem. Phys. 2010, 10, 11401-11413. [CrossRef]

53. Xing, W.L.; Yang, L.; Zhang, H.; Zhang, X.; Wang, Y.; Bai, P.C.; Zhang, L.L.; Hayakawa, K.; Nagao, S.; Tang, N. Variations in Traffic-Related Polycyclic Aromatic Hydrocarbons in PM2.5 in Kanazawa, Japan, after the Implementation of a New Vehicle Emission Regulation. J. Environ. Sci. 2022, 121, 38-47. [CrossRef]

54. Yang, L.; Suzuki, G.; Zhang, L.L.; Zhou, Q.Y.; Zhang, X.; Xing, W.L.; Shima, M.; Yoda, Y.; Nakatsubo, R.; Hiraki, T.; et al. The Characteristics of Polycyclic Aromatic Hydrocarbons in Different Emission Source Areas in Shenyang, China. Int. J. Environ. Res. Public Health 2019, 16, 2817. [CrossRef]

55. Oliveira, C.; Martins, N.; Tavares, J.; Pio, C.; Cerqueira, M.; Matos, M.; Silva, H.; Oliveira, C.; Camões, F. Size Distribution of Polycyclic Aromatic Hydrocarbons in a Roadway Tunnel in Lisbon, Portugal. Chemosphere 2011, 83, 1588-1596. [CrossRef] [PubMed]

56. Byambaa, B.; Yang, L.; Matsuki, A.; Nagato, E.G.; Gankhuyag, K.; Chuluunpurev, B.; Banzragch, L.; Chonokhuu, S.; Tang, N.; Hayakawa, K. Sources and Characteristics of Polycyclic Aromatic Hydrocarbons in Ambient Total Suspended Particles in Ulaanbaatar City, Mongolia. Int. J. Environ. Res. Public Health 2019, 16, 442. [CrossRef] [PubMed]

57. Yang, L.; Tang, N.; Matsuki, A.; Takami, A.; Hatakeyama, S.; Kaneyasu, N.; Nagato, E.G.; Sato, K.; Yoshino, A.; Hayakawa, K. A Comparison of Particulate-Bound Polycyclic Aromatic Hydrocarbons Long-Range Transported from the Asian Continent to the Noto Peninsula and Fukue Island, Japan. Asian J. Atmos. Environ. 2018, 12, 8. [CrossRef]

58. Nguet, J.; Albinet, A.; Leoz-Garziandia, E.; Budzinski, H.; Villenave, E. Reactivity of Polycyclic Aromatic Compounds (PAHs, NPAHs and OPAHs) Adsorbed on Natural Aerosol Particles Exposed to Atmospheric Oxidants. Atmos. Environ. 2012, 61, 15-22. [CrossRef]

59. Yang, L.; Zhang, X.; Xing, W.L.; Zhou, Q.Y.; Zhang, L.L.; Wu, Q.; Zhou, Z.; Chen, R.; Toriba, A.; Hayakawa, K.; et al. Yearly Variation in Characteristics and Health Risk of Polycyclic Aromatic Hydrocarbons and Nitro-PAHs in Urban Shanghai from 2010-2018. J. Environ. Sci. 2021, 99, 72-79. [CrossRef] [PubMed] 
60. LaCourse, D.L.; Jensen, T.E. Determination of 1-nitropyrene in extracts of vehicle particulate emissions. Anal. Chem. 1986, 58, 1894-1895. [CrossRef]

61. Morgott, D.A. Factors and Trends Affecting the Identification of a Reliable Biomarker for Diesel Exhaust Exposure. Crit. Rev. Environ. Sci. Technol. 2014, 44, 1795-1864. [CrossRef] [PubMed]

62. Atkinson, R.; Arey, J. Atmospheric Chemistry of Gas-Phase Polycyclic Aromatic Hydrocarbons: Formation of Atmospheric Mutagens. Environ. Health Perspect. 1994, 102, 117-126. [CrossRef] [PubMed]

63. Kakimoto, H.; Matsumoto, Y.; Sakai, S.; Kanoh, F.; Arashidani, K.; Tang, N.; Akutsu, K.; Nakajima, A.; Awata, Y.; Toriba, A.; et al Comparison of Atmospheric Polycyclic Aromatic Hydrocarbons and Nitropolycyclic Aromatic Hydrocarbons in an Industrialized City (Kitakyushu) and Two Commercial Cities (Sapporo and Tokyo). J. Health Sci. 2002, 48, 6. [CrossRef]

64. Orakij, W.; Chetiyanukornkul, T.; Kasahara, C.; Boongla, Y.; Chuesaard, T.; Furuuchi, M.; Hata, M.; Tang, N.; Hayakawa, K.; Toriba, A. Polycyclic Aromatic Hydrocarbons and Their Nitro Derivatives from Indoor Biomass-Fueled Cooking in Two Rural Areas of Thailand: A Case Study. Air Qual. Atmos. Health 2017, 10, 747-761. [CrossRef]

65. World Health Organization. The World Health Report 2000: Health Systems: Improving Performance; World Health Organization: Geneva, Switzerland, 2000; ISBN 92-4-156198-X.

66. Collins, J.F.; Brown, J.P.; Alexeeff, G.V.; Salmon, A.G. Potency Equivalency Factors for Some Polycyclic Aromatic Hydrocarbons and Polycyclic Aromatic Hydrocarbon Derivatives. Regul. Toxicol. Pharmacol. 1998, 28, 45-54. [CrossRef] [PubMed]

67. United States Environmental Protection Agency, Office of Emergency and Remedial Response. Risk Assessment Guidance for Superfund; Office of Emergency and Remedial Response, US Environmental Protection Agency: Washington, DC, USA, 1989.

68. Site, G.C. Hopewell Precision Area Groundwater Contamination Contamina Tion Site Town of East Fishkill, Dutchess County; U.S. EPA, Hopewell Junction: New York, NY, USA, 2012.

69. U.S. EPA. Exposure Factors Handbook: 2011 Edition (Final Report), U.S. Environmental Protection Agency, Washington, DC (2011), EPA/600/R-09/052F. Available online: https:/ / cfpub.epa.gov/ncea/risk/recordisplay.cfm?deid=236252 (accessed on 21 October 2019).

70. U.S. EPA. Risk Assessment Guidance for Superfund: Human Health Evaluation Manual (Part E, Supplemental Guidance for Dermal Risk Assessment); EPA/540/R/99/005; Office of Superfund Remediation and Technology Innovation: Washington, DC, USA, 2004.

71. Ali, N. Polycyclic Aromatic Hydrocarbons (PAHs) in Indoor Air and Dust Samples of Different Saudi Microenvironments; Health and Carcinogenic Risk Assessment for the General Population. Sci. Total Environ. 2019, 696, 133995. [CrossRef] [PubMed]

72. Yang, Q.; Chen, H.; Li, B. Polycyclic Aromatic Hydrocarbons (PAHs) in Indoor Dusts of Guizhou, Southwest of China: Status, Sources and Potential Human Health Risk. PLoS ONE 2015, 10, e0118141. [CrossRef] [PubMed]

73. Golobokov, A.S. Russian Naval Activity in the Asia-Pacific: The Herald for a New Alliance? Korean J. Def. Anal. 2019, 31, 613-633.

74. Saneev, B. Regional Priorities of the Eastern Energy Policy of Russia. E3S Web Conf. 2019, 77, 01006. [CrossRef] 